\title{
Digital activism: After the hype
}

Kaun, Anne; Uldam, Julie

Published in:

New Media \& Society

DOI:

10.1177/1461444817731924

Publication date:

2018

Document Version

Peer reviewed version

Citation for published version (APA):

Kaun, A., \& Uldam, J. (2018). Digital activism: After the hype. New Media \& Society, 20(6), 2099-2106.

https://doi.org/10.1177/1461444817731924

\section{General rights}

Copyright and moral rights for the publications made accessible in the public portal are retained by the authors and/or other copyright owners and it is a condition of accessing publications that users recognise and abide by the legal requirements associated with these rights.

- Users may download and print one copy of any publication from the public portal for the purpose of private study or research.

- You may not further distribute the material or use it for any profit-making activity or commercial gain.

- You may freely distribute the URL identifying the publication in the public portal.

Take down policy

If you believe that this document breaches copyright please contact rucforsk@kb.dk providing details, and we will remove access to the work immediately and investigate your claim. 


\section{Accepted Author Version, for citation}

Kaun A, Uldam J (2017) Digital Activism - After the Hype. New Media and Society doi: $10.1177 / 1461444817731924$

\section{Editorial Introduction Special Issue Digital Activism}

Guest Editors: Anne Kaun \& Julie Uldam

\section{Digital Activism - After the Hype}

In recent years, digital activism has emerged as yet another hot topic in both academia and beyond. For example, according to Google's ngram graph, references to digital activism steadily increased since the mid1990s and pundits have often alluded to and (over-) emphasized the role that digital technologies play for protest mobilization (Gerbaudo, 2017). Michael Hardt links the emergence of digital activism to what seems like a speeding-up of the protest cycles where a focus on media and communication aspects of social movement organization and an increasingly swift rate of technological change gives an impression of "accelerated rhythms of political shifts" (Hardt, 2017, p. 90).

When examining this phenomenon, we have to remember that the term digital activism is broad and ambiguous (Yang 2016). Definitions include activism that engages both fixed and mobile devices with access to the internet such as different forms of hacktivism, denial of service attacks, hashtag activism and open source advocacy (Joyce, 2010) or definitions that include all digital media used for political purposes (Gerbaudo, 2017). Currently, digital activism is studied within a wide range of disciplines, including anthropology, sociology, political science, media and communication studies as well as art and design studies. The field hence comprises a rich and at the same time disparate body of knowledge with diverse epistemologies and focal points. Political science and sociological inquiries, for example, focus on mobilization and opportunity structures as well as framing and information diffusion processes, including the role of networks (Bennett \& Segerberg, 2013; Garrett, 2006; González-Bailón, Borge-Holthoefer, Rivero, \& Moreno, 2011), while cultural studies approaches emphasize the broader contexts in which digital activism occurs (Yang, 2009). As such, digital activism is a growing field. However, it lacks a cohesive mode of inquiry (Joyce, 2010) that can leverage the advantages of different disciplinary insights and bring diverse perspectives and approaches into conversation.

This special issue explores this multiplicity of activism and uses digital media for specific political causes by engaging with diverse meanings of digital activism and examining the practices and affordances of political and civic contexts in which digital activism emerges. In doing so, the special issue includes contributions by scholars studying digital activism in China, Europe, Russia and the US. Rather than assuming a media-deterministic view of digital technologies and their implications for activism, this acknowledges the significance of different localities and contexts for the ways in which digital activism emerges. At the same time, the issue suggests a broad understanding of digital media. It includes discussions of the role of corporate social media such as Facebook (Clark; Kaun \& Uldam) and Twitter (Ferrari), but also stretches beyond these dominant platforms to include open source software (Velkova), forgotten websites and their remembering (Yang) as well as a nationalist memes war that unfolded on different Chinese social media platforms (Repnikova \& Fang). 


\section{Histories of Digital Activism and Media-determinism}

Although the hype around digital activism is arguably a recent phenomenon, there is an overemphasis on newness in many studies of digital activism across different disciplines contexts, although the "digital revolution" started much earlier than with rise of social media in the 2010s. However, there are only rare attempts to historicize the role of digital media for political activism. Before mobile phones, video handheld cameras and personal computers have changed the way social movements self-organized and documented their activities (Askanius, 2012). In an attempt to historicize digital activism, Trebor Scholz (2010) links political practices to the history of the internet, going back to the 1970s. His focus remains, however, on technological development rather than activism. In contrast, Todd Wolfson (2014) traces the origins of the cyber left in the US back to the Zapatista movement in Mexico in the 1990s as one of the first movements to explicitly include "a network of communication among all our struggles" which in turn inspired activists in the US. While Wolfson is an excellent example of historicizing digital activism, his focus remains on the US. Thus, there is a major research gap on histories of digital activism beyod this single dominant context.

Even though a more thoroughly written history of digital activism seems to still be missing, there are a few attempts at a periodization of digital activism. Defining digital activism as political participation and protest organized in digital networks, Athina Karatzogianni (2015) explores four waves of digital activism. She identifies the first wave as starting in 1994 with the Zapatista movement and antiglobalization movement, including alternative media such as Indymedia. The second wave of digital activism stretches from 2001 until 2007 and is mainly constituted by the rise of digital activism linked to anti-Iraq war mobilizations. During the third wave after 2007, digital activism spreads to the BRICS and other countries beyond Europe and the US, where it had initially originated. The fourth wave between 2010 to 2013 marks the mainstreaming of digital activism that is dominated by discussions of large-scale digital state surveillance unveiled by Wikileaks and Snowden (Karatzogianni, 2015). Similarly, Paolo Gerbaudo (2017) distinguishes two periods of digital activism. He identifies a first wave of digital activism in the mid-1990s characterized by cyber-autonomism within the anti-globalization movement and a second wave of the 2010s, which alludes to cyberpopulism as constituted within the mass mobilizations of Occupy, the movements of the squares and the anti-austerity movements. In Gerbaudo's periodization cyber-autonomism that is oriented towards autonomous communication is contrasted with cyber-populism with a techno-political orientation that is instituted by a web of commercial internet platforms such as Facebook, Twitter and Google and is mainly geared towards mass outreach.

While both periodizations are insightful, they struggle to balance a focus on the evolving media technologies with ideological changes and the socio-political context within which digital activism evolves. Especially Gerbaudo is critical of technological determinism and foregrounds an ideological analysis of digital activism practices. This surely contributes to a much-needed political and contextualized understanding of digital activism. However, it tends to lose sight of the character of activism that is specific to different digital media and formats. Hence, it lacks media-specificity in its historical analysis.

\section{Digital Media and the Myth of Universality}

Digital media in relation to digital activism are often considered as universal in the ways in which activist use them for political purposes. Countering these assumptions, Mary Joyce (2010) points to political, economic and societal norms as contextual factors conditioning digital activism. Similarly, Emiliano Treré, Sandra Jeppesen and Alice Mattoni (2017) emphasize the temporal and geographic dimensions of digital activism. Exploring anti- 
austerity protests in Spain, Italy and Greece, they examine different imaginaries of digital media's potential for political and social change. They conclude that activists in the three countries have distinct ideas about digital media, ranging from technopolitical (Spain) to techno-fragmented (Italy) and techno-pragmatic (Greece). According to this typology, Spanish activists' imaginaries of digital media are grounded in politics and political economies of communication. Following these imaginaries, activists relied heavily on technologies emerging from the free culture movement. In Italy, in contrast, activists lacked a cohesive imaginary and were not able to bring together old and new logics of media protests. Greek activists' imaginaries were largely based on practical objectives that served in same cases very different politics. Instead of following a certain technological and political program, the ideas reflected an ad hoc attitude that depended strongly on the specific and shifting purposes and individual attitudes of media makers within the movement. The important point in these two exemplifying studies is that we need to look beyond digital media affordances and also consider political, economic and societal norms as contextual factors conditioning activist uses of digital media.

From the wide range of different disciplinary approaches to digital activism, the research strands on the historicity and on practices of digital activism are thus dominated either by a strong focus on the digital, i.e. technology, emphasizing a universal way of using certain devices or infrastructures, or they foreground activism losing sight of the specificities of protest media technologies. Both approaches have their specific merits, but risk failing to address the significance of the interrelations between digital media on the one hand and political and civic culture on the other. Moving beyond this dualism, this special issue has been motivated by a wish to consider digital media as technical artifacts, communicative practices and institutional arrangements, as suggested by Lievrouw (2011). In this view, material artifacts or devices "enable and extend people's abilities to communicate and share meaning" (Lievrouw, 2011, p. 7) while activists develop particular practices as they appropriate the material artifacts that are embedded in larger institutional arrangements and civic cultures. This entails understanding technology as a cultural form as proposed by Raymond Williams, namely that technologies are expressions of larger social and political structures rather than being independent of them. As activism emerges within and in response to societal context, so do media technology, including digital media. Hence, the character and form of media technologies are shaped by social, political and economic needs and practices, while they in turn shape the very possibilities for self-expression, political participation and activism (Joerges, 1999; Williams \& Edge, 1996; Winner, 1980). Consequently, we approach digital activism as deeply situated.

\section{Contributions}

The contributions in this soecial issue explore two main issues relating to digital activism around a two-dimensional axis of digital technologies and activist practices. Firstly, that digital activism is often explored in ahistorical ways that foreground a technology-centred perspective. Secondly, that many studies reinforce the myth that digital media are used in a universal manner to promote political change. This special issue aims to counter both tendencies with a collection of articles that focus on digital activism in different regional contexts and take into account both digital technologies and activist practices. In doing so, they in different ways tell histories of digital activism. The articles gathered in this issue focus on contemporary forms of activism, while acknowledging their predecessors to capture the changing affordances of media technologies for activism over time. The modes of activism explored in these contributions represent a broad understanding of digital activism, ranging from media activism targeting media infrastructures and institutions itself to mediated 
activism employing different media platforms to promote their causes. In that sense, we aim to counter dominant epistemologies of seeing digital media as an exceptional force and the idea that technologies are used in a universal way (Hornborg, 2016).

The issue opens with the contribution by Guobin Yang and Shiwen $\mathrm{Wu}$, which engages with narratives of disappeared websites in China. The narratives capture the mourning and remembering of the websites with a strong engagement as the users foreground the emotional investment rather than their instrumental value. The analyzed narratives show that early forms of forums (bulletin board systems) that have now disappeared were spaces of camaraderie, sociality and community as well as spaces for an open and free expression and critical thinking. The sites are remembered for the passion, community and a sense of youthful idealism that they once spurred. These memories are retrospective as well as prospective. One the hand, they are mourning the loss of a golden age with possibilities of free exchange. On the other hand, the narratives constitute an expression of online activism against internet censorship. The article not only provides an in-depth analysis of the narratives, but also considers itself as a political and academic intervention of preserving and engaging with stories that might as well disappear.

The second article written by Rosemary Clark-Parsons engages with a discussion of the notion of feminist safe spaces in the context of corporate social media. More concretely, the analysis is based on an ethnographic inquiry into a secrete Facebook group for female identifying users providing a safe and supportive environment for discussion. Looking at how the Facebook group creates safety from, for and to, Clark-Parsons disentangles discursive and technological affordances on Facebook to develop an in-depth understanding of feminist safe spaces in the digital age.

Julia Velkova's contribution explores the repair aspect in free software development as situated digital infrastructuring. Starting point are cultural production practices in the context of limited access to digital tools in Russia. With the aim to produce animation films, producers and programmers - both local and international - collaborate to "repair" free software solutions to further their applicability to their purposes. Counter to many discussions that emphasize the politics of the free software movement, Velkova focuses on the slow, mundane and fragile aspects of repairing as part of free software beyond hacker cultures. The article concludes by discussing software infrastructures as situated that rejects their universality. Instead they are redefined as constant objects of contestation and re-negotiation through practices such as repairing.

Through the lens of the "little pink" meme war that unfolded in 2016, the article by Maria Repnikova and Kecheng Fang engages with the notion of cyber nationalism in China. The meme war emerged as mainland China nationalists mobilized against the election results in Taiwain by appropriating a discussion on gender in a forum for literature fans. The aim was to reframe the nationalist imaginary employing seemingly young girls as voices in a heated political debate. Repnikova and Fang showcase the ambivalence of digital activism through the little pink case and point to the blurring of boundaries between cyber nationalism and digital activism.

Taking the migration crisis of 2015 as an example, Anne Kaun and Julie Uldam introduce an analytical model to investigate civic engagement in corporate social media platforms.

Exploring Swedish volunteer initiatives tackling the immediate consequences of the migration crisis organized primarily with the help of Facebook. Based on interviews with central figures 
of these new initiatives, the article considers power relations, technological affordances, practices, and discourses that helps to shed light on the interrelation between social media and civic participation. The results point to a professionalization of communicative practices and coordination of volunteer work and discusses the consequences if crucial civic engagement that partially replaced government actions - is relying exclusively on corporate social media.

The final contribution by Elisabetta Ferrari explores user-generated political satire in Italy. Focusing on political fake accounts in social media, the article presents political faking and satire as a form of digital activism. It disentangles personal histories of activism and a repress political context within which digital activism emerges as a temporary extension of offline political activism and civic engagement. Considering both ideological reasons and personal trajectories of political engagement, the article provides a contextualized analysis of digital activism.

Together, the contributions traverse a two-dimensional axis of digital technologies and activist practices, striking the balance between context and media-determinism. In this way, the issue shows that there is a continued need for historicizing digital activism beyond focusing on the development of one device, platform or format, but following the complex activist digital media ecology over time (Treré \& Mattoni, 2015). Acknowledging the importance of digital media technologies, the issue provides examples of studying digital activism in a situated and radically contextualized manner that go beyond both digital universalism and digital exceptionalism (Marwick, 2013). The contributions provide mediumspecific analyses without lapsing into technological determinism.

The issue represents a broad range of digital activism both when it comes to the digital media employed and in terms of the political projects. In its entirety, it reflects a vivid field of research and diverse space for activism that includes feminism online, cybernationalism, Twitter publics, free software movement, political satire, political memory work as well as volunteering organized online. Often community building is at the heart of the digital activism explored here while digital media allow for new forms of cultural and political practices to emerge. The online and the digital becomes in that context a mediator for local, situated configurations that allude to the cultural boundedness and groundedness of digital activism.

As digital activism is an increasingly popular term in academic and popular debates, its ambiguity is simultaneously the reason for its popularity and its problems as a catch-all term that sits well with increasing polarizations within digital activism, spanning radical politics and revolutionary aspirations as well as NGO corporatization (Yang, 2016). The special issue hopes to revitalize and continue a vivid discussion of digital activism beyond its initial hype, unpacking a range of the technologies and practices that it comprises. The balance between paying attention to both the digital and the activism is a difficult one to strike, but we believe the collection of contributions in this special issue meet this objective.

\section{Funding}

The special issue presents the outcome of the DigAct network that was generously funded by STINT - Swedish Foundation for International Cooperation in Research and Higher

Education.

\section{References}


Askanius, T. (2012). Radical online video. YouTube, video activism and social movement media practices. Unpublished PhD thesis. Lund: Lund University.

Bennett, L., \& Segerberg, A. (2013). The Logic of Connective Action. Digital Media and the Personalization of Contentious Politics. New York: Cambridge University Press.

Garrett, K. (2006). Protest in an Information Society: a review of literature on social movements and new ICTs. Information, Communication \& Society, 9(2), 202-224.

Gerbaudo, P. (2017). From Cyper-Autonomism to Cyber-Populism: An Ideological History of Digital Activism. TripleC: Communication, Capitalism \& Critique, 15(2), 478-491.

González-Bailón, S., Borge-Holthoefer, J., Rivero, A., \& Moreno, Y. (2011). The Dynamics of Protest Recruitment through an Online Network. Scientific Reports, 1. doi:doi:10.1038/srep00197

Hardt, M. (2017). Multiple Temporalities of the Movements. TripleC: Communication, Capitalism \& Critique, 15(2), 390-392.

Joerges, B. (1999). Do Politics have Artefacts? Social Studies of Science, 29(3), 411-431.

Joyce, M. e. (2010). Digital Activism Decoded. The New Mechanics of Change. New York: International Debate Education Association.

Karatzogianni, A. (2015). Firebrand Waves of Digital Activism 1994-2014: The Rise and Spread of Hacktivism and Cyberconflict. London: Palgrave Macmillan.

Lievrouw, L. (2011). Alternative and Activist New Media. Cambridge: Polity.

Marwick, A. (2013). Status Update: Celebrity, Publicity, and Branding in the Social Media Age. New Haven, London: Yale University Press.

Scholz, T. (2010). Infrastructure: Its Transformations and Effect on Digital Activism. In M. Joyce (Ed.), Digital Activism Decoded: The New Mechanics of Change (pp. 17-31). New York: Idebate Press.

Treré, E., Jeppesen, S., \& Mattoni, A. (2017). Comparing Digital Protest Media Imaginaries: Antiausterity Movements in Spain, Italy and Greece. TripleC: Communication, Capitalism \& Critique, 15(2), 405-424.

Treré, E., \& Mattoni, A. (2015). Media ecologies and protest movements: main perspectives and key lessons. Information, Communication and Society, 19(2), 290-306. doi:10.1080/1369118X.2015.1109699

Williams, R., \& Edge, D. (1996). The Social Shaping of Technology. Research Policy, 26, 856-899.

Winner, L. (1980). Do artefacts have politics? Daedalus, 109(1), 121-136.

Wolfson, T. (2014). Digital rebellion: The birth of the cyber left. Urbana, Chicago, Springfield: University of Illinois Press.

Yang, G. (2009). The Power of the Internet in China: Citizen Activism Online. New York: Columbia University Press.

Yang, G. (2016). Activism. In B. Peters (Ed.), Digital Keywords: A Vocabulary of Information Society and Culture (pp. 1-17). Princeton, Oxford: Princeton University Press. 